\title{
Slanking anno 1863 - og 2010?
}

\author{
Markedet flommer over av selvhjelpsbøker med hensikt å hjelpe oss ned i vekt. Mange tror kanskje at dette er \\ et nytt fenomen, men den første bestselgeren kom så tidlig som i 1863. Den gang som nå, var diett et kontro- \\ versielt tema.
}

\author{
Magnus Strømmen \\ magnus-s@online.no \\ Institutt for nevromedisin \\ Medisinsk fakultet \\ Norges teknisk-naturvitenskapelige universitet \\ 7491 Trondheim \\ og \\ Regionalt senter for sykelig overvekt \\ Kirurgisk klinikk \\ St. Olavs hospital

\section{Bård Kulseng} \\ Regionalt senter for sykelig overvekt \\ St. Olavs hospital
}

Om hyllene i bokhandelen mest reflekterer hva som opptar oss, eller hva det ligger penger i, så er det trolig to sider av samme sak. Bokhandelen er i så måte et godt eksempel på markedets selvregulerende krefter. $\mathrm{Og}$ gitt at alt mellom to permer kan kalles litteratur, så er bøkene som skildrer veien til en smalere midje, et litterært tema som vokser i antall hyllemeter. Med titler vi ikke ønsker å gjengi, vekkes våre forhåpninger om strammere bukskinn og snarveier ned i vekt, tross matinntak mer eller mindre ad libitum.

Mange tror kanskje at dette er en ny litterær sjanger. Men så lenge skrivekyndige har observert overvektige, er fenomenet blitt behørig beskrevet. Allerede i antikken ble ikke bare fedme, men også dens konsekvenser og antatte adekvate behandling, nedtegnet (1). Men mens Hippokrates' kolleger henvendte seg til de lærde, er selvhjelpsbøker et nyere fenomen.

Skjønt nytt? Det som gjerne betraktes som den første slankeboken, var en pamflett utgitt i 1863, kalt Letter on Corpulence, Addressed to the Public (2). Forfatter var William Banting, en tykkfallen engelskmann som selv følte fedmens konsekvenser på kroppen. Trykksaken ble umiddelbart omtalt i medisinske tidsskrift (3) og kom i sin samtid til å foreligge i flere utgaver på en rekke språk, deriblant på svensk allerede tre år senere (4). Banting, bosatt i victoriatidens London, hadde ingen klinisk bakgrunn, men drev det godt der klinikerne gjerne slipper taket - $\mathrm{i}$ begravelsesbransjen. I voksen alder hadde imidlertid vekten tatt til å øke, tross et angivelig meget aktivt liv.
I flere tiår henvendte Banting seg til ulike leger for hjelp med lidelser sekundære til fedmen, uten å oppleve at noe hjalp ham løse det underliggende problemet. Dette skjedde i en tid hvor medisinere like gjerne vektla overvektens gunstige effekter som dens negative, og som en reaksjon på Bantings publikasjon, ga legen Edward Smith ut pamfletten How to get Fat, or the Means of Preserving the Medium between Leanness and Obesity (5). Bantings frustrasjon over legenes manglende kunnskap, så vel som forståelse av fedmens konsekvenser, kommer til uttrykk i hans egen tekst: «Oh! that the faculty would look deeper into, and make themselves better acquainted with, the crying evil of obesity - that dreadful tormenting parasite on health and comfort. Their fellow-men might not then descend into premature graves, as I believe many do, from what is termed apoplexy, and certainly would not, during their sojourn on earth, endure so much bodily and consequently mental infirmity» (6).

\section{Nye kostvaner}

Forsøkene på å gå ned i vekt var mange. Banting ble foreskrevet alt fra sjøluft og bad i kildevann til fysisk aktivitet. En lege anbefalte roing, et råd han også fulgte, og Banting kunne ses på elven flere timer i uken. Muskelkraften økte, men det samme gjorde både matlyst og vekt. På et tidspunkt - Banting er nå midt i 60 -årene - begynner også hørselen å svikte. Banting oppsøkte nok en lege, dr. Harvey, som ifølge Banting selv endelig så helseproblemene hans i sammenheng. Harvey foreskrev en diett som i seg selv skulle lede til vekttap, og derigjennom bedring av leddproblemer og navlebrokk, så vel som sviktende hørsel.

Løsningen var en diett bestående av lite sukker og stivelse. Hans tidligere inntak av brød, øl og poteter ble forlatt til fordel for et kosthold han selv betegner som den rene luksus. Til frokost spiste han $170 \mathrm{~g}$ kjøtt eller fisk, en kjeks eller toast. Middagen var til forveksling lik frokost, men med et tillegg av grønnsaker dyrket over marken og litt frukt. Middagen gled ned med 2-3 glass lett rødvin, sherry eller madeira. Ved «teatime» var kokt frukt, et par kjeks og, selv- sagt, te uten sukker. Kveldsmat var $100 \mathrm{~g}$ kjøtt eller fisk, 1-2 glass rødvin (eller sherry), før eventuelt søvnen ble hilst velkommen med et par glass vin eller en drink.

Noen fristelser blant karbohydratene kunne likevel ikke forsakes fullstendig: «Being fond of green peas, I take them daily in the season, and I gain 2 or $3 \mathrm{lbs}$. in weight as well as some little in bulk, but I soon lose both when their season is over. For this trespass I quite forgive myself» (6).

Med motivasjonen på topp fulgte han rådene systematisk og noterte vektutviklingen i tiden som fulgte. Banting gikk ned 50 pund, fra en BMI på $34 \mathrm{~kg} / \mathrm{m}^{2}$ som er fedme etter WHOs indeks (7), stabiliserte han seg i flere år omkring $25 \mathrm{~kg} / \mathrm{m}^{2}$, øvre grense for normalvekt. Livvidden ble redusert med hele $33 \mathrm{~cm}$.

\section{Rykter og motstand}

Det lå penger i dette. Mens Bantings første to utgaver ble distribuert gratis, tok han betaling for tredje utgave. På denne tjente han $£ 969$ (6), hvilket omregnet til dagens verdi skulle tilsvare i underkant av $£ 616000$ (8), en nett sum for et relativt tynt hefte. Ikke uventet ble han beskyldt for å spekulere $i$ andres ulykke. Til sin egen integritets forsvar redegjorde derfor Banting i fjerdeutgaven for hver shilling han hadde tjent. Overskuddet ble i sin helhet gitt til ulike sykehus og institusjoner for trengende, og Banting ble slik en av sin tids velgjørere.

Forordet i fjerdeutgaven dveler mye ved kritikken Banting møtte. Motstanden tok form av alt fra ryktespredning til skarpe innlegg i medisinske journaler. Kritikken omhandlet flere forhold, så som hvem som skulle krediteres for å ha funnet opp kuren $(9,10)$, men også det utidige faktum at en legmann syslet med medisinsk litteratur: «We advice Mr. Banting, and everyone of his kind, not to meddle with medical literature again, but be content to mind his own business» (9).

I lys av vår tids økende detaljkunnskap om fedmens fysiologi kan vi nok se The Lancets påstand fra 1864 om at «the professional literature about corpulence is tolerably complete» (9) som noe drøy. Imidlertid kunne samme tidsskrifts karakteristikk av 
fete mennesker, «...the fact that few fat people possess any great power of selfdenial or much physical energy. So they give a day or two to the diet, and then drift back to the sweets of life» (9), vært et utsagn

\section{«Muskelkraften økte, men det samme gjorde både matlyst og vekt»}

tilskrevet også mange klinikere av i dag. Først på 1930-tallet kom medisinske tidsskrift for alvor til å se mer kritisk på overvekt og fedme (11).

En annen type kritikk dreide seg om helsefaren forbundet ved å følge dietten. I BMJ brukes skjebnen til en høyesterettsdommer som en advarsel til publikum. Beskrivelsen sier også noe om samtidens syn på fedme (vår utheving):

«Mr. Justice Williams is at last pronounced out of danger. For weeks he has been hovering between life and death. It is to be hoped, that those of our readers who are tempted to try the effect of the Banting system to reduce that obesity which nature has given them will think a little of Mr. Justice Williams before adopting it, for it is certain that the serious illness of the learned judge was occasioned by the use of Bantingism» (12).

Men Banting hadde også tilhengere blant legene. I 1870 kom boken On Diet and the Regimen in Sickness and Health (13) hvor dr. Dobell refererte til kritikken av Banting: «Mr. Banting has done a great deal more good than harm. He has not brought forward a single new fact or new idea, but he has had the luck, by zealously advertising a striking case of the effects of a plan of treatment long familiar to every medical man who understood physiology, to convince the public of the immense influence on the animal organism of modifications in the quality of food - an influence in the importance of which they did not half believe when urged upon them in the form of medical advice.»

\section{Fra Banting til Atkins}

Flere aspekter ved Bantings suksess var problematisk. Den gang som nå, var det kontroverser knyttet til å anbefale én type kost, og det gjorde ikke saken bedre at Banting selv manglet klinisk bakgrunn. Men kanskje like vanskelig å svelge var at - som Dobell skriver-Banting nådde ut til folk på en måte medisinerne ikke greide. Dette skyldtes i stor grad at han delte sine egne personlige

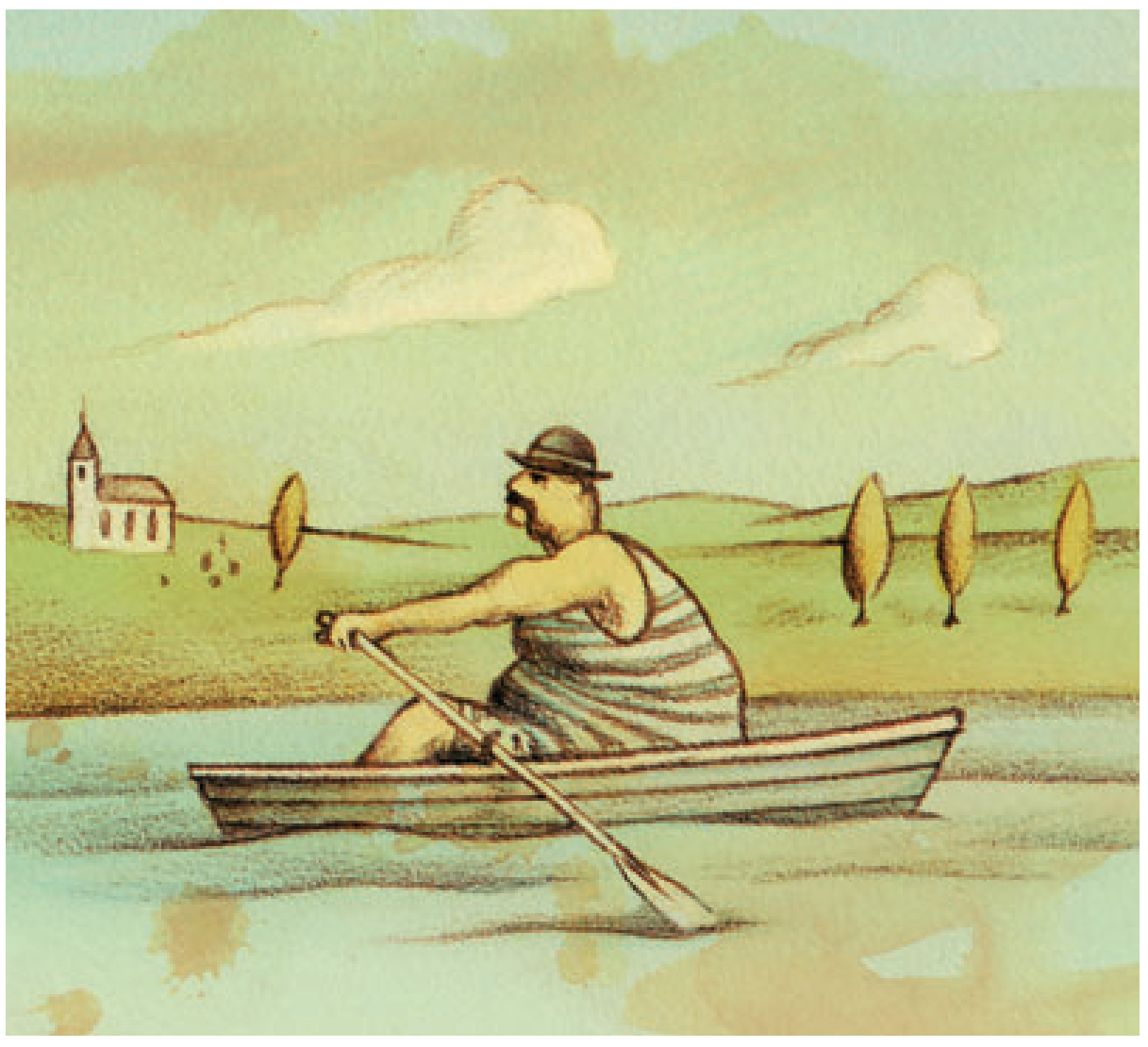

Illustrasjon Stein Løken

erfaringer. Og nettopp slik kom hans Letter on Corpulence til å bli en litterær nyhet, i form av en selvbiografisk slankebok.

Få er forunt å bli udødeliggjort i form av eponymer, men «banting», som gikk inn i det engelske språket ensbetydende med «to diet», viser altså til «The undertaker» William B., og ikke Sir Frederick B., hvis oppdagelse av insulinet kan sies å være en større medisinsk milepæl. Ordet fant også veien til Sverige hvor man snakker om «att banta» og «bantning», mens det er fremmed på norske tunger. Banting var et innarbeidet uttrykk i England allerede ved utgangen av 1860-årene, den gang mer presist $\mathrm{i}$ betydningen lavkarbohydratdiett.

Slike dietter er siden blitt promotert av flere som selv har erfart dens effekter. Mest kjent er dr. Atkins, som med sine 45 millioner solgte bøker har satt William Banting i skyggen. Fortsatt diskuteres diettens langsiktige effekter på helse og vekt i medisinske tidsskrift, og det er interessant å se at The Lancet har vært åsted for slike diskusjoner allerede fra Bantings tid frem til i dag $(9,14)$.

William Banting døde 81 år gammel.

Oppgitte interessekonflikter: Ingen
Litteratur

1. Christopoulou-Aletra H, Papavramidou N. Methods used by the hippocratic physicians for weight reduction. World J Surg 2004; 28: 513-7.

2. Banting W. Letter on corpulence, addressed to the public. London: Harrison, 1863.

3. Anonymous. A cure for corpulence. BMJ 1864; 1 : 99-100.

4. Edholm E. Bantings kur mot korpulens. Stockholm: P. A. Norstedt \& Söner, 1866.

5. Gilman SL. Obesity and diet in the nineteenth century: Framing Verdi and Boito's Healthy Falstaff. University of Toronto Quarterly 2005; 74: 759-75.

6. Banting W. Letter on corpulence, addressed to the public. 4 utg. London: Harrison, 1869.

7. Verdens helseorganisasjon. Obesity. Preventing and managing the global epidemic. Rapport nr. 894. Genève: WHO, 2000.

8. Valutakalkulator. Measuring worth. www.measuringworth.com/ukcompare (20.10.2010).

9. Anonymous. Bantingism. Lancet 1864; 1: 520.

10. Harvey J. To the Editor of The Lancet. Lancet 1864 1: 571 .

11. Zweiniger-Bargielowska I. The culture of the abdomen: Obesity and reducing in Britain, circa $1900-1939$. Journal of British Studies 2005; 44: $239-73$.

12. Bruker vi Anonymous? Bantingism. BMJ 1864; 1 : 345.

13. Dobell HB. On diet and regimen in sickness and health. London: H. K. Lewis, 1872.

14. Astrup A, Larsen TM, Harper A. Atkins and other low-carbohydrate diets: hoax or an effective tool for weight loss? Lancet 2004: 364: 897-9.

Manuskriptet ble mottatt 11.8. 2010 og godkjent 23.9. 2010. Medisinsk redaktør Jon Amund Kyte. 